\title{
ON SPLENIC LYMPH AND ITS HEMOLYTIC ACTION
}

\author{
HIROHIDE HATTA, KEN-ICHI OKADA, SATOSHI MORITA \\ AND HISATO MISHIMA* \\ Department of Physiology, School of Medicine, Hiroshima University, Kure, Japan
}

Experiments on splenic lymph have been unsatisfactory. Barcroft and Florey (1) reported that blood stained lymph was seeping into the clear fluid of the cisterna chyli when the splenic mesentery was occluded. It was because of a difficulty in collecting the pure splenic lymph. These authors have succeeded in collecting the pure splenic lymph and measuring the flow volume, protein content and rapidity of substances in passing from the blood to the splenic lymph. It was found by chance that erythrocytes in the splenic lymph were hemolyzed on standing. From this fact, it was thought that hemolytic substances would probably be contained in it. In the present experiments hemolytic action of the splenic lymph was examined.

\section{METHOD}

Method of collecting the splenic lymph. Dogs were anesthetized with urethane. The abdomen was opened by median and transverse incisions. The latter was parallel to and $2 \mathrm{~cm}$. below the left costal margin. In order to collect the pure splenic lymph, the spleen was isolated from the connected organs by the following operation. The anterior layer of the gastro-splenic omentum was cut off from the greater curvature, and the greater omentum, which covered the intestines, was also removed from the spleen. The right and left short gastric arteries and the short and coronary gastric veins were collectively ligated with the posterior layer of the greater omentum. The tail of the pancreas was removed from the base of the splenic mesentery, and then the lymphatic vessels, which ran along the portal vein from the liver and duodenum, were ligated between the splenic and liver lymph nodes. Lastly, the fold of the peritoneum was cut between the spleen and colon. By this operation, the spleen was completely isolated and suspended on the mesenteric root. A polyvinyl tube was inserted into an efferent lymphatic vessels, derived from the splenic lymph nodes, and other efferent lymphatic vessels were ligated. Another opening of the tube was connected with a pipette, which was changed every five minutes to measure the flow volume and protein content. The protein content was measured with Abbé's refractometer. The serum or plasma in

Received for publication May 10, 1955.

* 八田博英, 岡田乾一, 森田 聰, 三飠人人 
the blood withdrawn from the jugular vein, was used as a blood sample.

Preparation of erythrocytes suspension. Erythrocytes obtained from the anticoagulative blood of the dog's jugular vein were used. A few ml. of erythrocytes were washed several times with Ringer solution $(\mathrm{NaCl} \ldots 0.90$, $\mathrm{CaCl}_{2} \ldots 0.02, \mathrm{KCl} \ldots 0.02$, water $\ldots$ 100.0, p $_{\mathrm{H}} 7.1$, phosphate buffer), and 5 per cent $(\mathrm{v} / \mathrm{v})$ suspension was prepared.

Measurement of hemolysis. All experiments were done in vitro. The lymph for test was used after centrifugation. Erythrocytes suspension $(0.02 \mathrm{ml}$.) was put into test-tubes containing $0.10 \mathrm{ml}$. of lymph (or plasma), Ringer solution $(2.0 \mathrm{ml}$.) being added lastly after a given period of standing. The content of each test-tube was centrifugated. The oxy-hemoglobin $\left(\mathrm{HbO}_{2}\right)$ content in supernatant was measured in $414 \mathrm{~m} \mu$ wave length with Beckman's electric spectrophotometer (DU type). The percentage of hemolysis was calculated by the following formula.

$$
\text { percentage of hemolysis }=\frac{\text { Increase of } \mathrm{HbO}_{2} \text { content in supernatant }}{\mathrm{HbO}_{2} \text { content in erythrocytes suspension }} \times 100
$$

where, $\mathrm{HbO}_{2}$ content in erythrocytes suspension was measured $\mathrm{HbO}_{2}$ content of $0.02 \mathrm{ml}$. erythrocytes suspension in $2.10 \mathrm{ml}$. distilled water.

\section{RESULTS}

Flow and protein content of the splenic lymph. As shown in table 1 and $2 \neq 5$ and $\approx 6$, the volume of splenic lymph ranged from $0.002 \mathrm{cc}$. to $0.009 \mathrm{cc}$. per minute,

TABLE 1.

\begin{tabular}{c|c|c|c|c|c|c}
\hline $\begin{array}{c}\text { No. of } \\
\text { exp. }\end{array}$ & $\begin{array}{c}\text { Body } \\
\text { weight }\end{array}$ & $\begin{array}{c}\text { Spleen } \\
\text { weight }\end{array}$ & $\begin{array}{c}\text { Flow volume } \\
\text { (cc/min.) }\end{array}$ & $\begin{array}{c}\text { Protein } \\
(\%)\end{array}$ & $\begin{array}{c}\text { Plasma } \\
\text { protein } \\
(\%)\end{array}$ & $\begin{array}{c}\text { Splenic lymph } \\
\text { Plasma } \\
(\%)\end{array}$ \\
\hline 1 & 7.0 & - & 0.009 & 4.42 & 6.12 & 72 \\
2 & 6.5 & 65 & 0.002 & 362 & 5.37 & 67 \\
3 & 8.5 & 35 & 0.003 & 4.55 & 6.71 & 67 \\
4 & 13.0 & 68 & 0.004 & 4.73 & 7.30 & 66 \\
5 & 11.0 & 63 & 0.003 & 2.34 & 5.25 & 44 \\
6 & 10.0 & 31 & 0.006 & 3.56 & 6.94 & 52 \\
7 & 10.0 & - & 0.006 & 3.97 & 6.41 & 62 \\
\hline
\end{tabular}

TABLE 2. Protein Content of the Lymph

\begin{tabular}{|c|c|c|c|c|c|c|c|c|}
\hline $\begin{array}{l}\text { No. of } \\
\text { exp. }\end{array}$ & Spleen & $\begin{array}{c}\text { Thoracic } \\
\text { duct }\end{array}$ & $\begin{array}{c}\text { Right } \\
\text { lymph } \\
\text { duct }\end{array}$ & Liver & Intestine & $\begin{array}{l}\text { Cervical } \\
\text { lymph }\end{array}$ & Foot & Plasma \\
\hline 1 & 4.42 & 3.51 & - & - & - & - & - & 6.12 \\
\hline 2 & 3.48 & 3.52 & 4.09 & 4.38 & - & 0.72 & 1.31 & 5.83 \\
\hline 3 & 4.73 & - & - & - & - & - & 1.55 & - \\
\hline 4 & 4.73 & 4.03 & 3.05 & - & 3.21 & - & - & 6.41 \\
\hline 5 & & $\begin{array}{c}3.67 \\
(0.34)\end{array}$ & $\begin{array}{c}3.15 \\
(0.032)\end{array}$ & - & 3.51 & - & - & 7.30 \\
\hline 6 & $\begin{array}{l}2.45 \\
(0.006)\end{array}$ & $\begin{array}{c}2.80 \\
(0.16) \\
\end{array}$ & $\begin{array}{l}1.89 \\
(0.068)\end{array}$ & 3.51 & - & - & - & 4.96 \\
\hline
\end{tabular}

Notes : Figures parenthesized show flow volume (cc/min.). Unit ... per cent. 
and only $1 / 57$ to $1 / 27$ of thoracic duct lymph, corresponding to $1 / 11$ to $1 / 5$ of right lymph duct lymph. It had no relation to the spleen weight. It was accelerated by every expiratory movement as well as thoracic duct and liver lymph.

Its protein content ranged from 3.56 to 4.42 per cent corresponding to $52-72$ per cent of sera except in a case of table $2 \approx 5$. As shown in table 2 , its protein content was on a much higher level than those of the cervical and foot lymph, and a little higher than those of the thoracic duct, right lymph duct and intestinal lymph, but always on a lower level than that of the liver lymph.

Effect of occlusion of the splenic mesentery on the splenic lymph. When the splenic mesentery was occluded at its base for five minutes, the splenic lymph flow increased fourfold from $0.02 \mathrm{cc}$. to $0.08 \mathrm{cc}$. per five minutes, followed by a fall in protein content from 4.09 to 3.51 per cent. In another case, it increased to sevenfold. After this procedure it was more bloody stained and contained much more erythrocytes than before.

Effect of intravenous infusion of Ringer solution on the splenic lymph. When Ringer solution (250 cc., corresponding to one-third of the calculated blood volume) was rapidly infused into the jugular vein, the protein content of blood fell from 6.71 to 5.38 per cent and the splenic lymph flow increased ten minutes after infusion from $0.01 \mathrm{cc}$. to $0.05 \mathrm{cc}$. per five minutes, followed by a fall in protein content from 4.33 to 3.51 per cent. On the one hand, the lymph flow from the thoracic duct increased markedly, and was followed by a fall in the protein content from 4.35 down to 2.99 per cent, corresponding to a twofold fall as compared with that in the splenic lymph.

Passage of substances from the blood to the splenic lymph. Certain diffusible dyes solutions were injected into the jugular vein so that about 0.01 per cent of dye might be contained in the blood, calculating the volume of injection on an assumption that the dog's blood volume was one-thirteenth of the body weight. Concentration was determined by the paper-colorimetric methods, mentioned elsewhere (4). Time required for the passage of substances from the blood to the splenic lymph is shown in table 3. Fluorescein appeared very rapidly in the splenic lymph, and patent blue was next, and Evans blue the last to appear. The smaller the molecular weight of the substances, the less time they required to pass from the blood to the splenic lymph. Compared with results in lymph obtained from other sources, all dyes tested appeared most rapidly in the intestinal lymph and a little later in the splenic lymph. The dye concentrations in lymph 60 minutes after injection from different sources are shown in table 4. Dye concentration in the splenic lymph was kept as a rule on a lower level than those of the liver, thoracic duct and intestinal lymph, but on a much higher level than that of the cervical lymph. In some cases, it was on a higher level than those of the thoracic duct and intestinal lymph. However, even in such a case, it was always on a lower level than that of the liver lymph. 
TABLE 3. Time Required for the Passage of Dyes from the Blood to the Lymph

\begin{tabular}{c|c|c|c|c|c|c|c}
\hline $\begin{array}{c}\text { No. of } \\
\text { exp. }\end{array}$ & Dyes & Spleen & $\begin{array}{c}\text { Thoracic } \\
\text { duct }\end{array}$ & $\begin{array}{c}\text { Right } \\
\text { lymph } \\
\text { duct }\end{array}$ & Intestine & Liver & $\begin{array}{c}\text { Cervical } \\
\text { lymph }\end{array}$ \\
\hline 1 & Fluorescein & $1^{\prime} 40^{\prime \prime}$ & $2^{\prime}$ & $1^{\prime}$ & $1^{\prime}$ & - & - \\
2 & Patent blue & $7^{\prime}$ & $4^{\prime}$ & $4^{\prime}$ & $3^{\prime}$ & - & - \\
3 & "' & $6^{\prime}$ & $5^{\prime}$ & $4^{\prime} 30^{\prime \prime}$ & $3^{\prime}$ & - & - \\
4 & Evans blue & $13^{\prime}$ & - & - & $9^{\prime}$ & $12^{\prime}$ & - \\
$\mathbf{6}$ & ${ }^{\prime \prime}$ & $17^{\prime}$ & $30^{\prime}$ & - & $12^{\prime}$ & - & $28^{\prime}$ \\
\hline
\end{tabular}

TABLE 4. Dye Concentration in the Lymph, 60 Minutes after Injection (per cent)

\begin{tabular}{c|c|l|c|c|c|c|c}
\hline $\begin{array}{c}\text { No. of } \\
\text { exp. }\end{array}$ & Dyes & Spleen & $\begin{array}{c}\text { Thoracic } \\
\text { duct }\end{array}$ & $\begin{array}{c}\text { Right } \\
\text { lymph } \\
\text { duct }\end{array}$ & Intestine & Liver & $\begin{array}{c}\text { Cervical } \\
\text { lymph }\end{array}$ \\
\hline 1 & Fluorescein & 0.0075 & 0.0075 & 0.005 & 0.001 & - & - \\
2 & Patent blue & 0.001 & 0.003 & 0.0005 & 0.0025 & 0.0075 & - \\
3 & "l & 0.0025 & 0.005 & 0.001 & 0.005 & - & - \\
4 & Evans blue & 0.001 & - & - & 0.0008 & 0.0025 & 0.00025 \\
5 & $\prime \prime$ & 0.00075 & 0.001 & - & 0.0008 & 0.0020 & - \\
6 & "l & 0.0025 & 0.0023 & - & - & - & 0.00079 \\
\hline
\end{tabular}

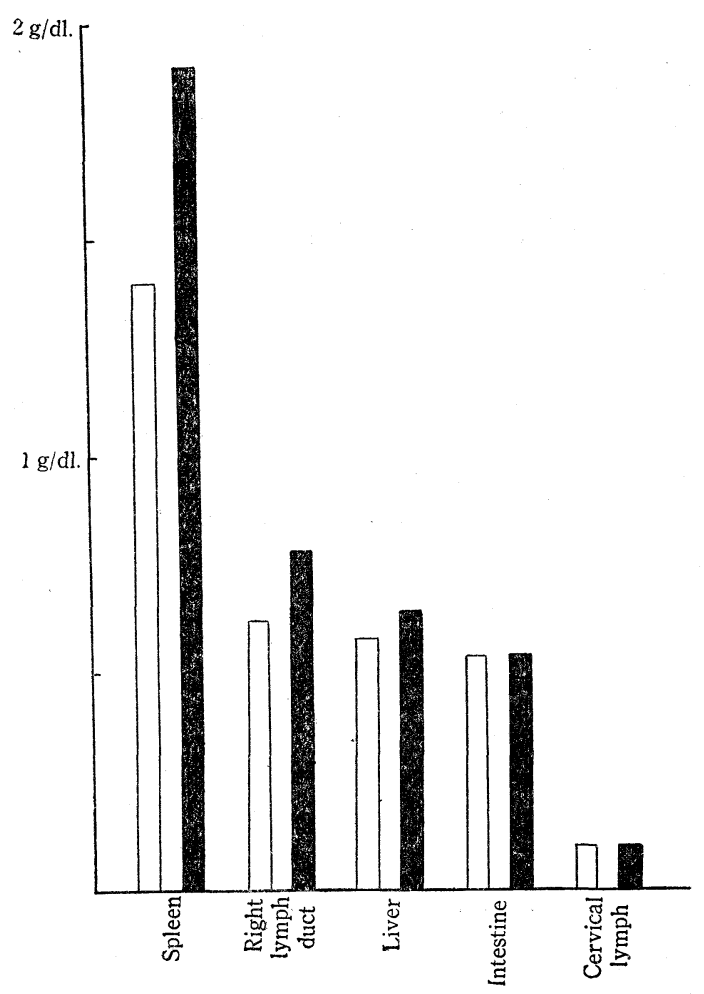

FIG 1. 
Hemoglobin content in the splenic lymph. The splenic lymph showed characteristic and specific absorptions in 414,540 and $576 \mathrm{~m} \mu$ wave length, corresponding to those of $\mathrm{HbO}_{2}$, and the lymph from other sources, also, showed similar and lower absorptions. The $\mathrm{HbO}_{2}$ contents in lymph varied according to their sources, as shown in white columns of fig. 1, in which, splenic lymph showed the highest value. Even when it was collected under the best conditions, its $\mathrm{HbO}_{2}$ value reached the level of $333-340 \mathrm{mg} / \mathrm{dl}$.

Hemolytic action of the splenic lymph. The hemolytic action was tested fifteen minutes after addition of erythrocytes suspension to the lymph. The results are shown in fig. 1 , in which black columns indicate $\mathrm{HbO}_{2}$ values after addition of erythrocytes suspension, and white columns, control values. The differences between these values showed increases in $\mathrm{HbO}_{2}$ values caused by hemolysis, in which the highest one was the increase in the splenic lymph, indicating the highest hemolytic action in the lymph from different sources.

Effect of dilution on hemolytic action of the splenic lymph. After a serial dilution of the splenic lymph with Ringer solution, the hemolytic action in each dilution was tested at 20 hour's intervals. The results obtained are shown in table 5. The splenic lymph in two-, four- and eightfold dilution showed higher hemolytic action, but below this dilution range hemolytic action decreased abruptly. The plasma in the jugular vein blood in two- and fourfold dilution showed hemolytic action.

TABLE 5. Effect of Dilution on Hemolytic Action of the Splenic Lymph

\begin{tabular}{c|c|c|c|c|c|c|c}
\hline Dilution & $\begin{array}{c}\text { Original } \\
\text { material }\end{array}$ & $2 \times$ & $4 \times$ & $8 \times$ & $16 \times$ & $32 \times$ & $64 \times$ \\
\hline $\begin{array}{c}\text { Splenic } \\
\text { lymph }\end{array}$ & 99 & 84 & 71 & 52 & 16 & 5 & 1 \\
\hline $\begin{array}{c}\text { Jugular } \\
\text { veinplasma }\end{array}$ & 100 & 63 & 43 & 13 & 3 & - & - \\
\hline
\end{tabular}

Notes: Unit ... per cent.

Effect of incubation on hemolytic action. After incubation (at $56^{\circ} \mathrm{C}$., for 30 minutes) hemolytic action of the splenic lymph increased as shown in fig. 2 . A part of $\mathrm{HbO}_{2}$ contained in it was converted into hematin by incubation.

Hemolytic action of the blood plasma of the spleen pulp. In order to obtain the blood of the spleen pulp, blood was withdrawn from the splenic mesentery, temporarily occluding its base immediately after contraction of the spleen, caused by electric stimulation of the splanchnic nerves.

As shown in fig. 3, hemolytic action of the spleen pulp plasma was on a higher level in each dilution than that of the splenic lymph and plasma in the jugular vein blood, whereas this was inhibited in the original material. Hemolytic action of the splenic lymph in each dilution ranked between the spleen pulp plasma and jugular vein plasma with an exception of the original material.

Inhibitory effect of hemoglobin on hemolysis. The relationship between hemolytic action of the plasma and the amount of $\mathrm{HbO}_{2}$ is shown in table 6 . In 

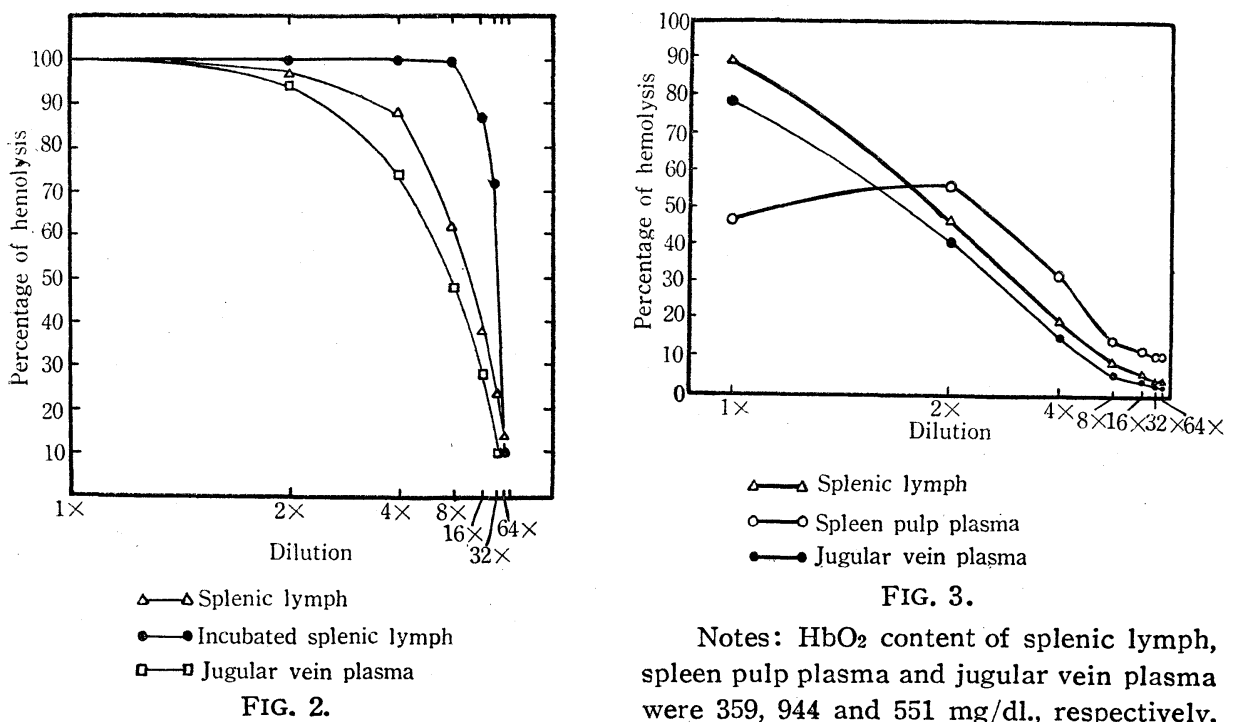

FIG. 3.

Notes: $\mathrm{HbO}_{2}$ content of splenic lymph, spleen pulp plasma and jugular vein plasma were 359, 944 and $551 \mathrm{mg} / \mathrm{dl}$., respectively.

TABLE 6. Relationship between Hemolytic Action of the Plasma and the Amount of $\mathrm{HbO}_{2}$

\begin{tabular}{c|c|c|c|c}
\hline $\begin{array}{c}\text { Concentration } \\
\text { of added HbO } \\
\text { (mg/dl) }\end{array}$ & 1887 & 943 & 471 & 235 \\
\hline $\begin{array}{c}\text { Percentage of } \\
\text { hemolysis }\end{array}$ & 6.9 & 13.1 & 27.2 & 37.2 \\
\hline
\end{tabular}

TABLE 7. Inhibitory Effect of $\mathrm{HbO}_{2}$ on the Hemolysis

\begin{tabular}{c|c|c|c}
\hline $\begin{array}{c}\text { Hours after addition of } \\
\text { erythrocytes suspension }\end{array}$ & 1 & 2 & 24 \\
\hline Jugular vein plasma & 24.3 & 41.0 & 84.6 \\
\hline $\begin{array}{c}\text { Jugular vein plasma plus } \\
\mathrm{HbO}_{2}(2030 \mathrm{mg} / \mathrm{dl} ., 0.10 \mathrm{ml} \text { ) }\end{array}$ & 0 & 28.3 & 49.8 \\
\hline
\end{tabular}

Notes: Unit ... per cent.

these experiments the given amounts $(0.10 \mathrm{ml}$.) of serial diluted solutions of $\mathrm{HbO}_{2}$ were added to the orginal materials of plasma. It was observed that hemolytic action of plasma was inhibited with increasing amounts of $\mathrm{HbO}_{2}$. A linear relationship was observed between the logarithm of concentration of $\mathrm{HbO}_{2}$ and the amount of hemolysis. Table 7 shows the effect of hemoglobin on the hemolytic action in given periods after addition of erythrocytes suspension. It was obvious that the inhibitory effect of $\mathrm{HbO}_{2}$ on the hemoytic action was observed when $\mathrm{HbO}_{2}$ was added to the tested system, that is, the percentage of hemolysis in the added system wasl ower than that of the control system at 1,2 and 24 hour's intervals. 


\section{DISCUSSION}

Concerning the presence of "open system" in the spleen blood capillaries, there are different opinions $(5,7,8,11,12,13)$. If it were present it would be expected that the solutes and the injected substances in blood readily appear in the splenic lymph in higher concentration than in the liver lymph. However, this can not be acertained from the results obtained, but the spleen blood capillaries seem to belong to the category of "closed system," showing relatively higher permeability than capillaries in other parts of the body.

Snook $(16,17)$ and other investigators (10) revealed that deep lymphatic plexuses piercing the white pulp are present in the spleens of the guinea-pig, mole, mouse, horse, and monkey, but this is not yet confirmed in the dog's spleen. Mall (9) also found no lymphatic channels in the white pulp sheath or nodules in the spleen of the dog. Contrary to these reports, the higher permeability of the capillaries in the dog's spleen suggests the presence of deep lymphatic plexuses.

Bergenhem (2), Fåhraeus (3) and Singer (15) postulate the existence of lysolecithin as a hemolytic substance in the plasma and tissues, which is contained more abundantly in the stagnated blood of the spleen than in the general circulating blood, and whose hemolytic action is abolished by incubation and decreased by shaking the plasma. The results obtained in our experiments agree with their opinions in that hemolytic action of the stagnated blood in the spleen pulp is higher than that of the general circulating blood, but disagree with them in that hemolytic action is increased by incubation (at $56^{\circ} \mathrm{C}$., for 30 minutes). Recently, Laser (6) denied the existence of lysolecithin in the body and isolated a hemolytic substance of high activity from the plasma and a number of animal organs, and claimed that its activity is considerably increased by hematin. In our experiments, increased hemolytic action of the splenic lymph after incubation may be due to the effect of hematin, which is converted from $\mathrm{HbO}_{2}$ by incubation.

The inhibitory effect of hemoglobin on hemolytic action has been observed by Laser (6). As shown in fig. 3. the inhibited action is observed only in the original material of the spleen pulp plasma. Such an inhibition is due to the effect of $\mathrm{HbO}_{2}$ contained, for the spleen pulp plasma contains a greater quantity of $\mathrm{HbO}_{2}$ than the general circulating blood and the splenic lymph, as shown in the foot notes of fig. 3. A similar inhibitory effect on the action of the splenic lymph is observed in the case shown in table 5 , in which the percentage of hemolysis is lower by one per cent than that of the jugular vein plasma.

From this it is supposed that the hemolytic substance in the splenic lymph may probably be similar to Laser's hemolytic substance.

At present it is difficult to make any assumption regarding the physiological significance of the presence of hemolytic substance in relatively large amounts in the right lymph duct lymph. However, the existence of hemolytic substance of high activity in the splenic lymph and spleen pulp plasma leads us to assume that this substance is related to normal destruction of erythrocytes 
in the spleen. Furthermore, the fact that the splenic lymph contains a large amount of $\mathrm{HbO}_{2}$ even in its best collecting conditions supports it.

\section{SUMMARY}

1. The method of collecting the splenic lymph of dogs is explained, by which the flow and protein content are measured.

2. The flow volume of the splenic lymph is very small and ranges from $0.002 \mathrm{cc}$. to $0.009 \mathrm{cc}$. per minute.

3 . The protein content is relatively higher, ranking to next the liver lymph, corresponding to 52-72 per cent of serum. A greater quantity of hemoglobin is contained in the splenic lymph even when collected under the best conditions.

4. Time required for dyes to pass from the blood into the splenic lymph is increased with an increase in the molecular weight of the substance. The dye concentration in the splenic lymph ranks under that of the liver lymph.

5. A hemolytic substance of high activity is contained in the splenic lymph. Hemolytic actitivity is inhibited by hemoglobin and accelerated by incubation (at $56^{\circ} \mathrm{C}$., for 30 minutes). The lymph dervied from other sources contained a hemolytic substance, whose activity is lower than that of the splenic $1 y m p h$.

\section{REFERENCES}

1. BARCROFT, J. AND H. W. FLOREY. Some factors involved in the concentration of blood by the spleen. J. Physiol. $66: 231.1926$.

2. BERGENHEM, B. AND R. FÅHRAEUS. Über spontane hämolysinbildung in Blut, under besonderer Berücksichtigung der Physiolgie der Milz. Z. ges. exp. Med. 97 : 555, 1936.

3. FiHRAEUS, R. The erythrocytes-plasma interface. Lancet $2: 630,1939$.

4. HATTA, H. AND K. OKADA. Observation on the passage of dyes from the blood to the intestinal lymph. J. Hiroshima Med. Ass. 5: Original series 654, 1952 (Japanese).

5. KNISELY, M. H. Microscopic observations on the circulatory system of living unstimulated mammalian spleen. Anat. Record $65: 23,1936$.

6. LASER, H. The isolation of a haemolytic substance from animal tissues and its biological properties. J. Physiol. $110: 338,1950$.

7. MAC Kenzie, D. V., A. O. Whipple AND M. P. Wintersteiner. Studies on the microscopic anatomy and physiology of living transilluminated mammalian spleen. Amer. J. Anat. $68: 397,1941$.

8. MAtsumoto, S. On the structure of the spleen blood vessels. Sei-i-kwai Zasshi 57: 2349, 1938 (Japanese).

9. MALL, F. P. The architecture and blood vessels of the dog's spleen. Zeitschrift $f$. Morphol. und Anthropol. 2: 1, 1909.

10. NAIto, E. On the deep lymphatic vessels in the spleen. Nippon Kaibō-gaku Zasshi 4 : 1429, 1938 (Japanese).

11. NAKATA, K. On the structure of the spleen. Soggo-igaku $11: 13,23,1953$ (Japanese).

12. NISIMARU, Y. AND STEGgerdA, F. R. Observations on the structure and function of certain blood vessels in the spleen. J. Physiol. $74: 324,1932$.

13. PECK, H. M. AND N, L. HOERR. The intermediary circulation in red pulp of the mouse spleen. Anat. Record 109: 447, 1951. 
14. PONDER, E. Haemolysis and related phenomen. New York: Waverly press, 1940.

15. SINGER, K. Lysolecithin and hemolytic anemia. The significance of lysolecithin production indifferentiation of circulating and stagnated blood. J. Clin. Invest. 20: 153, 1941.

16. SNOOK, T. The guinea-pig spleen. Studies on the structure and connection of venous sinus. Anat. Record 89: 413, 1944.

17. SNook, T. Deep lymphatics of the spleen. Anat. Record $94: 43,1946$. 